Research

\title{
Distribution and The Habitat Characteristics of Anopheles vagus (Diptera: Culicidae) Larvae at Paddy Fields in The Vicinity of Dramaga IPB University Campus Dramaga Bogor West Java
}

\author{
Dimas Novianto', Syifa Alya², Upik Kesumawati Hadi $3^{*}$, Susi Soviana ${ }^{3}$ \\ ${ }^{1}$ Graduate Student of Parasitology and Medical Entomology Division, Faculty of Veterinary Medicine, IPB University \\ ${ }^{2}$ Undergraduate Student, Faculty of Veterinary Medicine, IPB University \\ ${ }^{3}$ Department of Animal Infectious Diseases and Veterinary Public Health, Faculty of Veterinary Medicine, IPB University \\ *Corresponding author: upikke@apps.ipb.ac.id \\ Submitted April 14, 2021 Accepted May 17, 2021
}

\begin{abstract}
Dramaga sub-district is an area that has rice fields close to buffalo stalls and a population of wild Macaca fascicularis as natural hosts for several species of Plasmodium. This causes the Dramaga sub-district to become a potential vector habitat for malaria, including Anopheles vagus. This study aims to analyze distribution of An. vagus larval stage in 4 villages (Cikarawang, Babakan, Margajaya, and Ciherang) in Dramaga subdistrict which have paddy field areas. Larvae were collected using a dipper, and each collection sites of the larvae habitat were marked using Global Positioning System. The physical characteristics of the water habitat measured were temperature, $\mathrm{pH}$, total dissolved solids and the electrical conductivity of the water. Pearson's correlation test was used to analyze the relationship between the number of larvae An. vagus with each of the parameters water physical characteristics. The results of this study obtained 309 An. vagus larvae from the 27 collection points. Larvae of An. vagus was found in 3 villages (i.e. Cikarawang, Babakan and Ciherang), but was not found in Margajaya village. The habitat characteristics of An. vagus in paddy fields showed a water temperature of 26.6$31.7^{\circ} \mathrm{C}$, pH $6.40-8.10$, the total dissolved solid $36-285 \mathrm{ppm}$, and the electrical conductivity $72-262 \mu \mathrm{m} / \mathrm{cm}$. The Pearsons correlation test results did not show a significant difference between the number of An. vagus larvae and each parameter $(r=-0.26,0.13,-0.15$ and -0.16 , respectively). The presence of $A n$. vagus in this area could be considered in malaria vector control programs.
\end{abstract}

Keywords: mosquito, Anopheles vagus, IPB University

\begin{abstract}
ABSTRAK
Kecamatan Dramaga merupakan wilayah yang memiliki area persawahan yang dekat dengan kandang kerbau dan populasi Macaca fascicularis liar sebagai inang alami dari beberapa jenis Plasmodium. Hal tersebut menyebabkan kecamatan Dramaga potensial menjadi habitat vektor Malaria, termasuk Anopheles vagus. Penelitian ini bertujuan untuk menganalisis distribusi An. vagus stadium larva di area persawahan pada 4 desa (Cikarawang, Babakan, Margajaya, dan Ciherang) di Kecamatan Dramaga. Larva dikumpulkan dengan menggunakan mosquto dipper, dan setiap lokasi pengumpulan habitat larva ditandai dengan Global Positioning System. Karakteristik fisik dari habitat perairan yang diukur adalah suhu, $\mathrm{pH}$, total padatan terlarut dan daya hantar listrik air. Uji korelasi Pearson digunakan untuk menganalisis hubungan antara jumlah larva An. vagus dengan masing-masing parameter karakteristik fisik air. Berdasarkan penelitian diperoleh hasil sejumlah 309 larva An. vagus dari 27 titik pengumpulan. Larva dari An. vagus ditemukan di 3 desa, yaitu Cikarawang, Babakan dan Ciherang. Akan tetapi, tidak ditemukan di Desa Margajaya. Karakteristik habitat An. vagus, yaitu sawah yang menunjukkan suhu air $26,6-31,7^{\circ} \mathrm{C}, \mathrm{pH}$ 6,40-8,10, total padatan terlarut 36-285 ppm, dan daya hantar listrik $72-262$ $\mu \mathrm{m} / \mathrm{cm}$. Hasil uji korelasi Pearsons tidak menunjukkan hubungan yang signifikan antara jumlah larva An. vagus dan setiap parameter $(r=-0.26,0.13,-0.15$ dan -0.16 , berturut-turut). Kehadiran nyamuk An. vagus di lokasi ini harus dipertimbangkan dalam program pengendalian vektor malaria.
\end{abstract}

Kata kunci: nyamuk, Anopheles vagus, IPB University 


\section{INTRODUCTION}

Malaria is a vector-borne disease caused by parasites from the genus Plasmodium that can infect a wide variety of animals including humans. The transmission of malaria is mediated by the Anopheles mosquito as a vector. The variety of Anopheles species in Indonesia is quite high, namely around 81 species and 25 of them have been proven to be malaria vectors (Ministry of Health 2015). This vector is distributed throughout the region in Indonesia and each region has different species, bioecology, habitat, distribution and density. The existence and survival of Anopheles larvae are strongly influenced by the conditions of their breeding sites such as the physical characteristics of water.

The villages around the Dramaga IPB campus are residence for students, teaching staffs, education personnel and other academicians as well as the natives of Dramaga District. IPB students are very unique because they come from various regions in Indonesia, including from malaria endemic areas. Barodji (1980) and Andiyatu (2005) conducted research on the species diversity of mosquitoes in the villages surrounding the Dramaga IPB campus including rice fields. Both of them reported several genus of Anopheles mosquitoes including Anopheles vagus. The rice fields around the Dramaga IPB campus are also close to animal sheds such as buffalo, cow, goat, and also wild Macaca fascicularis habitats as natural hosts for various species of Plasmodium.

The existence of An. vagus needs serious attention as a potential vector of malaria. Wigati et al. (2006) reported An. vagus originating from Hargorejo Village, Kokap District, Kulon Progo Regency has been confirmed by ELISA containing circum sporozoite protein of Plasmodium falciparum. An. vagus and An. sinensis in Muara Enim, South Sumatra was also confirmed by ELISA containing $P$. falciparum and $P$. vivax (Budiyanto et al., 2017). In addition, Munif et al., (2019) reported An. vagus was also a companion vector during the outbreak of malaria in Sukabumi because it contained $P$. falcifarum with a sporozoite index of $0.12 \%$ and an inoculation rate of 0.213 .

Based on those informations, a study on the distribution and habitat characteristics of An. vagus larvae in the rice fields around the Dramaga IPB campus is important to study.

\section{MATERIAL AND METHODS}

The method used in this research was purposive sampling method. Anopheles larvae were collected using a dipper on watery rice fields in four villages around the Dramaga campus (Cikarawang, Babakan,
Ciherang and Margajaya). The mosquitoes that were successfully collected were put into a small container to be identified up to the species level using the key morphology of the larvae according to O'Connor and Soepanto (1989). Each collection point was marked using the Global Positioning System and presented in a distribution map of An. vagus. in rice fields in the village around the Dramaga campus. The physical characteristics of water that were measured include temperature, $\mathrm{pH}$, total dissolved solids, and electrical conductivity. The number of larvae that were collected was then performed the Pearson correlation test with each of the physical characteristics of the water.

\section{RESULTS AND DISCUSSION}

The results of this study obtained 309 Anopheles vagus larvae in 27 points of rice fields in Cikarawang Village, Babakan Village, and Ciherang Village, while in Margajaya Village they were not found ((Table 1 dan Fig. 1). The presence of An. vagus in the village rice fields around the campus was not evenly distributed. Rice fields in Cikarawang Village are the most points where An. vagus larvae can be found. The rice fields in Cikarawang Village are located close to residential areas that have buffalo and other livestock, while in Babakan, Ciherang, and Margajaya Villages, there are no buffalo stalls found around the rice fields. An. vagus was reported to have a preference for sucking animal blood (zoophilic) in Pesawaran and Muara Enim Districts (Hanafy 2015; Budiyanto et al. 2017).

The results of the measurement of the physical characteristics of water including $\mathrm{pH}$, temperature, total dissolved solid and electrical conductivity varied between points where An. vagus larva was found, however did not show a significant correlation between each measurement and the number of larvae found (Fig 2). The $\mathrm{pH}$ value of rice field water where An. vagus found was 6.40-8.10 (mean 7.37). In Ogan Komering Ulu Regency, Maretasari et al. (2019) reported the $\mathrm{pH}$ value in the rice fields of $A n$. vagus habitat was in acidic $\mathrm{pH}$ (5-6). Another study repoted that An. gambiae larvae lived in water with a $\mathrm{pH}$ of $4-7.8$ if there was sufficient food for consumption (Oyewole et al. 2009).

According to Clark et al. (2004) pH of water affects the successful breeding of mosquito larvae where mosquito larvae will die at $\mathrm{pH}<3$ and $>12$. Akhiriyanti and Nugroho (2019) reported neutral pH levels (6.8-7.2) have a higher potential (86.4\%) for breeding place of Aedes aegypti larvae. Neutral $\mathrm{pH}$ water conditions supported the plankton growth and its presence became a source of food 
Table 1 Results of Measurement Number of Larvae An. vagus, pH, temperature, the amount of dissolved solids, and the electrical conductivity of water in the Rice Fields Around IPB University

\begin{tabular}{|c|c|c|c|c|c|}
\hline Collection Site & $\begin{array}{c}\text { Number of } \\
\text { Larvae }\end{array}$ & $\mathrm{pH}$ & Temperature & TDS & EC \\
\hline 1 & 43 & 7,4 & 29,5 & 75 & 150 \\
\hline 2 & 48 & 7,6 & 27,7 & 55 & 110 \\
\hline 3 & 27 & 7,5 & 29,8 & 60 & 121 \\
\hline 4 & 31 & 7,5 & 28,2 & 45 & 90 \\
\hline 5 & 25 & 7,6 & 27,9 & 52 & 104 \\
\hline 6 & 14 & 7,3 & 27,5 & 85 & 165 \\
\hline 7 & 10 & 7,4 & 27,6 & 45 & 144 \\
\hline 8 & 3 & 7,3 & 27,5 & 66 & 122 \\
\hline 9 & 15 & 7,2 & 27,2 & 61 & 175 \\
\hline 10 & 1 & 7,3 & 29 & 87 & 220 \\
\hline 11 & 6 & 7,6 & 29,5 & 285 & 142 \\
\hline 12 & 3 & 7,9 & 30,4 & 130 & 173 \\
\hline 13 & 15 & 7,6 & 29,6 & 132 & 262 \\
\hline 14 & 4 & 7,8 & 28,7 & 98 & 199 \\
\hline 15 & 2 & 7,8 & 28,7 & 92 & 206 \\
\hline 16 & 14 & 7,7 & 28,6 & 123 & 247 \\
\hline 17 & 1 & 7 & 29,2 & 80 & 161 \\
\hline 18 & 1 & 7,1 & 29,2 & 74 & 158 \\
\hline 19 & 17 & 7 & 27,4 & 82 & 116 \\
\hline 20 & 7 & 7,1 & 26,6 & 85 & 170 \\
\hline 21 & 8 & 6,4 & 26,9 & 78 & 154 \\
\hline 22 & 3 & 6,9 & 29,2 & 77 & 136 \\
\hline 23 & 3 & 7 & 30,2 & 72 & 145 \\
\hline 24 & 4 & 7,6 & 29,3 & 78 & 157 \\
\hline 25 & 1 & 7,1 & 29,7 & 36 & 72 \\
\hline 26 & 1 & 8,1 & 30,2 & 39 & 79 \\
\hline 27 & 2 & 7,4 & 31,7 & 41 & 77 \\
\hline
\end{tabular}

for mosquito larvae (Sunarti et al. 2018).

The temperature of the rice fields where An. vagus larvae found was between $26.6-31.7{ }^{\circ} \mathrm{C}$ (mean $28.78^{\circ} \mathrm{C}$ ). This temperature is still in line with the research of Kenglueca et al. (2005) who stated that larva An. vagus in Northwestern Thailand can be found in water temperatures of $25.4-32{ }^{\circ} \mathrm{C}$. Rice fields are areas without shade so that sunlight can penetrate the water and provide a higher temperature value than areas shaded by trees. Warm water in sunlit habitats may be an important factor for larval development because warm water speeds up their development. In addition, warm temperatures allow more microbes to develop microorganisms that provide a food source for mosquito larvae (Minakawa et al. 1999).

Total dissolved solid value and water electrical conductivity in paddy-field where An. vagus was found hold a range of value of TDS (36-285) ppm 
140 | Novianto et al.

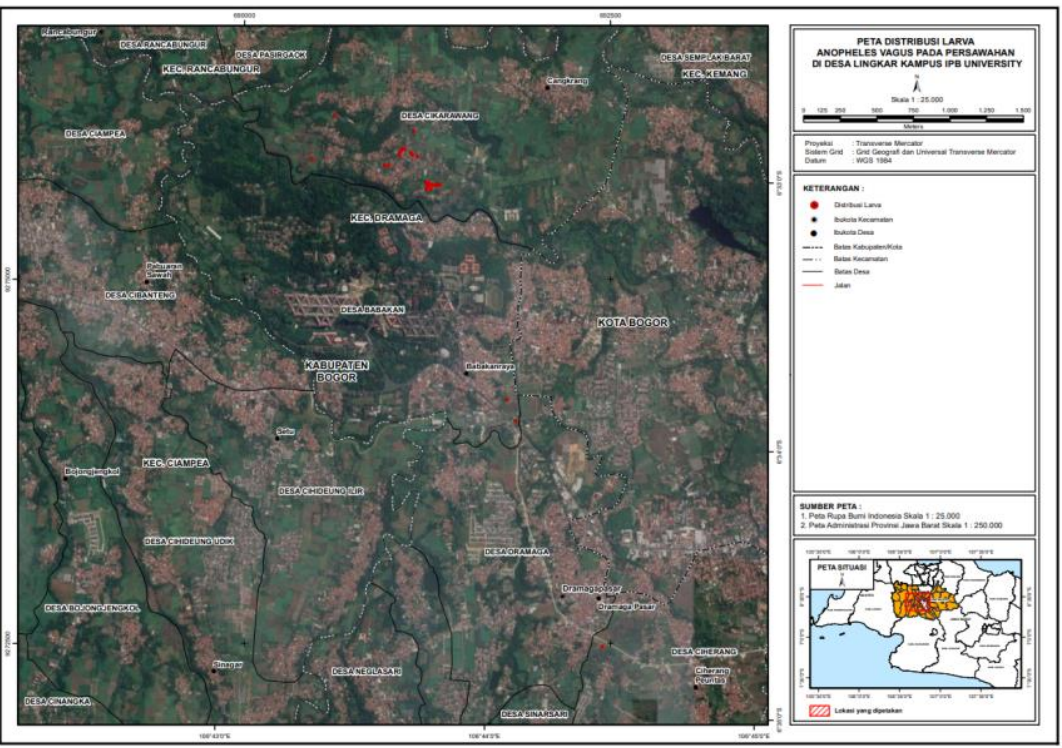

Figure 1 Distribution of An. vagus larvae in paddy-field in in the villages around the Dramaga IPB campus, Bogor
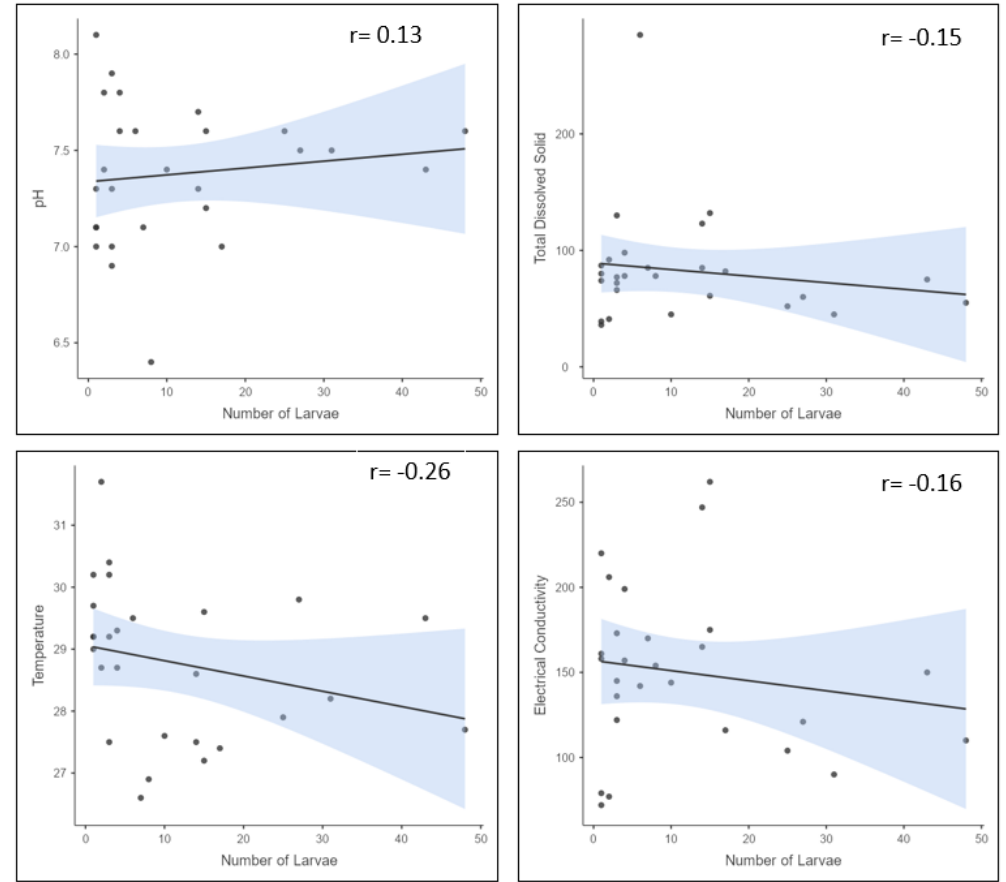

Figure 2 Scattered Plot on An. vagus Larvae numbers with $\mathrm{pH}$, temperature, total dissolved solid and electrical conductivity on paddy-field

while EC (71- 262) $\mu \mathrm{m} / \mathrm{cm}$. In accordance to Astuti (2014), a larger value on TDS in a liquid imposes a probability of higher numbers of ion in the liquid, which makes the electricity conductivity in a larger value. Water $\mathrm{EC}$ value hold a negative correlation to An. Arabiensis larvae density. Anopheles gambiense larvae and An. arabiensis were detected in an environment where water conductivity is low and water electricity conductivity is above $2000 \mu \mathrm{m} / \mathrm{cm}$ which impose significant larvae decrease (Fillinger et al., 2009). High electricity conductivity caused by salinity and dissolved ion may trigger a negative impact on mosquito larvae growth (Closs et al., 2003).

The TDS (total dissolved solid) and EC (electrical conductivity) values of water in rice fields where $A n$. vagus found were $36-285 \mathrm{ppm}$ and $71-262 \mu \mathrm{m} / \mathrm{cm}$, respectively. According to Astuti (2014) the greater value of total dissolved solids (TDS) in the solution, 
the greater the possibility of the number of ions in the solution, so that the electrical conductivity (EC) value is greater. Fillinger et al. (2009) reported the value of the electrical conductivity of water has a negative correlation with the density of larvae An. arabiensis. An. gambiense and An. arabiensis larvae were found in the habitat where the water conductivity was low and the water electrical conductivity was above $2000 \mu \mathrm{m} / \mathrm{cm}$ and caused a significant decrease in larvae. High electrical conductivity due to salinity and dissolved ions can have a negative impact on the growth of mosquito larvae (Closs et al. 2003).

\section{REFERENCE}

Akhiriyanti V, Handoyo W. 2019. Determinan keberadaan jentik di wilayah pedesaan endemis demam berdarah Dengue. Jurnal Kesehatan Masyarakat Indonesia 14(2): 24-28.

Andiyatu. 2005. Fauna Nyamuk di Wilayah Kampus IPB Dramaga dan Sekitarnya serta Potensinya sebagai Penular Penyakit. Tesis S2. Sekolah Pascasarjana, Institut Pertanian Bogor. Bogor.

Astuti AA. 2014. Kualitas air irigasi ditinjau dari parameter $\mathrm{DHL}, \mathrm{TDS}, \mathrm{pH}$ pada lahan sawah Desa Bulumanis Kidul Kecamatan Margoyoso. Jurnal Litbang 10(1): 35-42.

Barodji. 1980. Jenis dan Populasi Nyamuk di Daerah Persawahan Desa Darmaga dan Ciderum Kabupaten Bogor. Tesis S2. Sekolah Pascasarjana, Institut Pertanian Bogor. Bogor.

Brei B, Edman JD, Gerade B, Clark JM. 2004. Relative abundance of two cuticular hydrocarbons indicates whether a mosquito is old enough to transmit malaria parasites. Journal of Medical Entomology 41(4): 807-809.

Budiyanto A, Ambarita LP, Milana Salim. 2017. Konfirmasi Anopheles sinensis dan Anopheles vagus sebagai vektor malaria di Kabupaten Muara Enim Provinsi Sumatera Selatan. Aspirator 9(2): 51-60.

Closs G, Downes B, Boulton A. 2003. Freshwater Ecology. Blackwell Publishing. Malden.

Fillinger $\mathrm{U}$, Sombroek $\mathrm{H}$, Majambere $\mathrm{S}$, van Loon $\mathrm{E}$, Takken W, Lindsay SW. 2009. Identifying the most productive breeding sites for malaria mosquitoes in The Gambia. Malaria Journal 8(1): 1-4.
Hanafy I. 2015. Keanekaragaman Jenis, Kepadatan Dan Aktivitas Mengisap Darah Anopheles (Diptera: (ulicidae) pada Aplikasi Zooprofilaksis di Daerah Endemis Malaria. Tesis S2. Sekolah Pascasarjana, Institut Pertanian Bogor. Bogor.

[Kemenkes] Kementerian Kesehatan RI. 2015. Profil Pengendalian Penyakit Bersumber Binatang (PPBB). 2015. Kementerian Kesehatan Press. Jakarta.

Kengluecha $A$, Singhasivanon $P$, Tiensuwan $M$, Jones JW, Sithiprasasna R. 2005. Water quality and breeding habitats of anopheline mosquito in northwestern Thailand. Southeast Asian Journal of Tropical Medicine \& Public Health 36(1): 46-53.

Maretasari G, Windusari Y, Lamin S, Hanum L, Septiawati D. 2019. Characteristics of habitat, distribution, and diversity of Anopheles spp in Kemelak Bindung Langit Village, Ogan Komering Ulu Regency, South Sumatra. Journal of Environmental Science and Sustainable Development 2(2): 4.

Minakawa N, Mutero CM, Githure JI, Beier JC, Yan G. 1999. Spatial distribution and habitat characterization of anopheline mosquito larvae in Western Kenya. The American Journal of Tropical Medicine and Hygiene 61(6): 1010-1016.

Munif A, Rusmiarto S, Aryati Y, Andris H. Stoops CA. 2019. Konfirmasi status Anopheles vagus sebagai vektor malaria pendamping saat kejadian luar biasa malaria di Kabupaten Sukabumi Indonesia. Jurnal Ekologi Kesehatan 7(1): 689-696.

O'Connor CT, Soepanto A. 1989. Kunci Bergambar Identifikasi Jentik Anopheles $\mathrm{Di}$ Indonesia Anopheles Betina. Ditjen PPM \& PLP, Depkes RI. Jakarta.

Oyewole IO, Momoh OO, Anyasor GN, Ogunnowo AA, Ibidapo CA, Oduola OA, Obansa JB, Awolola TS. 2009. Physico-chemical characteristics of Anopheles breeding sites: Impact on fecundity and progeny development. African Journal of Environmental Science and Technology 3(12): 447-452

Sunarti, Ali MS, Mudatsir. 2018. Kepadatan fitoplankton dan larva nyamuk Aedes albopictus pada tempat perindukan di Kecamatan Syiah Kuala Kota Banda Aceh. Jurnal Biotik 6(2): 125-130.

Wigati RA. 2006. Inkriminasi nyamuk Anopheles vagus Donitz 1902 (Diptera: Culicidae) sebagai vektor malaria di Kecamatan Kokap, Kabupaten Kulon Progo, Provinsi Daerah Istimewa Yogyakarta. Tesis S2. Sekolah Pascasarjana, Universitas Gadjah Mada. Yogyakarta. 